Vol. 11 (2002): 219-231.

\title{
Effects of traffic and fertilization levels on grass yields in northern Norway
}

\author{
Birger Volden
}

Planteforsk, The Norwegian Crop Research Institute, Vagønes Research Station, N-8010 Bodø, Norway, e-mail: birger.volden@planteforsk.no

Tore E. Sveistrup, Marit Jørgensen

Planteforsk, The Norwegian Crop Research Institute, Holt Research Centre, N-9292 Troms $\phi$, Norway

Trond K. Haraldsen

Jordforsk, Norwegian Centre for Soil and Environmental Research, Frederik A. Dahls vei 20, N-1432 Ås, Norway

\begin{abstract}
Experiments with various traffic regimes in grassland (no traffic, light and medium tractor with two mechanisation lines; forage harvester and two-step harvesting) and three fertilization levels (N 120, $180,240 \mathrm{~kg} \mathrm{ha}^{-1}$ ) were carried out in five fields on sandy soils and peat soils in Bodø, northern Norway. Increased tractor weight caused significant decrease in yields on the peat soils with both mechanisation lines. When the peat soils were exposed to the light tractor treatments, DM yields increased significantly as the fertilization level rose from $\mathrm{N} 120 \mathrm{~kg} \mathrm{ha}^{-1}$ to $\mathrm{N} 180 \mathrm{~kg} \mathrm{ha}^{-1}$, but not for further increase to $\mathrm{N} 240 \mathrm{~kg} \mathrm{ha}^{-1}$. With the medium tractor treatments, there was no significant yield increase from $\mathrm{N} 120 \mathrm{~kg} \mathrm{ha}^{-1}$ to $\mathrm{N} 180 \mathrm{~kg} \mathrm{ha}^{-1}$, but a further increase to $\mathrm{N} 240 \mathrm{~kg} \mathrm{ha}^{-1}$ gave significantly higher yields. Use of lighter machines on peat soils may therefore lead to reduced fertilizer costs for farmers, and decrease the risk of leaching from the soil. On the sandy soils, yields were significantly lower at the medium tractor treatment with two-step harvest compared to no traffic. With the exception of decreased air-filled porosity at $1-5 \mathrm{~cm}$ depth of the peat soils no significant change in soil physical properties of the plough layer were measured. Therefore, the negative impact of traffic on plant growth was more likely due to plant injury than impaired soil conditions.
\end{abstract}

Key words: compaction, fertilizers, grasslands, peat, sand, tracks

\section{Introduction}

Grassland occupies more than $90 \%$ of the cultivated land in northern Norway. Due to a short growing season, and unstable and wet weather conditions, harvesting is often carried out on wet soils. The grassland yields may vary considerably, both due to winter damage caused by ice cover or ponding of the soil surface, and soil compaction and damage of the grass sward caused by agricultural traffic. Based on traffic 
Volden, B. et al. Effects of traffic and fertilization on grassland yields

experiments on various soils in different parts of Sweden Håkansson et al. (1990) concluded that the yield reduction in leys was due primarily to mechanical injury of the plants rather than to soil compaction. Haraldsen et al. (1995) showed that yield loss due to soil compaction in grassland in northern Norway varied between soils. On soils susceptible to soil compaction (loamy and clayey soils) yield loss was observed already in the first year leys, while in peat soils yield loss due to soil compaction increased with the age of the leys. Thomas and Evans (1975) concluded that low aeration of the surface layer of the soil, due to compaction by vehicles and livestock, was a major obstacle to better grassland production in England and Wales. Increased fertilizer application may partly compensate for poor root development and supply sufficient nutrients to the plants when heavy machinery is used. Such effects have been reported by Wopereis et al. (1990).

Previous investigations on soil compaction in northern Norway have been carried out by driving over the field with a tractor in such a way that tracks covered from $125 \%$ to $600 \%$ of the surface area (Haraldsen et al. 1995, Sveistrup and Haraldsen 1997). Håkansson et al. (1990) made use of two traffic intensities at each of three harvest times in their Swedish studies. However, results from experiments with a traffic regime similar to farming practice combined with different fertilizer levels have been lacking. The two-step harvest system implies several passes in the same tracks and may reduce the surface area covered by tracks compared with the use of a forage harvester. This could reduce the area affected by soil compaction and reduce the direct effects on the plants. Therefore, field experiments with different harvesting systems using three levels of fertilizer were established on five fields in 1998 at Vågønes, Bodø, northern Norway. The aim of the study was to examine the effects of traffic intensity under varying fertilizer levels, and to test whether the two-step harvest system could be less harmful to soils and plants than the forage harvest systems.

\section{Material and methods}

\section{Soils and botanical composition in the experimental fields}

Haraldsen and Grønlund (1989) and Haraldsen and Sveistrup (1996) have described the soils in the experimental fields. Basic soil information for the fields is shown in Table 1. The soil in the three fields with mineral soil was relatively homogenous, well sorted, dominated by fine and medium sand $(80-92 \%$ in the fraction $0.06-$

Table 1. Basic soil information for the experimental fields.

\begin{tabular}{llllcc}
\hline $\begin{array}{l}\text { Type of } \\
\text { grassland }\end{array}$ & $\begin{array}{c}\text { Seeding } \\
\text { year }\end{array}$ & Soil type & $\begin{array}{l}\text { Drainage class } \\
\text { (FAO 1990) }\end{array}$ & $\begin{array}{c}\mathrm{pH} \\
0-20 \mathrm{~cm}\end{array}$ & $\begin{array}{c}\text { Ignition loss } \\
\mathrm{g} / 100 \mathrm{~g} \\
0-20 \mathrm{~cm}\end{array}$ \\
\hline Pasture & 1982 & Fine sand & Well & $5.0 / 5.4^{1}$ & 6.4 \\
Established ley & 1996 & Fine sand/loamy sand & Moderate & 6.7 & 5.0 \\
New ley & 1998 & Fine sand/loamy sand & Moderate & 5.4 & 5.0 \\
Established ley & 1994 & $\begin{array}{l}\text { Moderately to strongly } \\
\text { decomposed peat }\end{array}$ & Poorly & 6.8 & 40.1 \\
& 1998 & $\begin{array}{l}\text { Moderately to strongly } \\
\text { decomposed peat }\end{array}$ & $\begin{array}{l}\text { Very poorly/ } \\
\text { poorly }\end{array}$ & 6.1 & 60.4 \\
\hline
\end{tabular}

${ }^{1} 0-5 \mathrm{~cm} / 5-20 \mathrm{~cm}$ 
Vol. 11 (2002): 219-231.

Table 2. Dominating grass species in the experimental fields ( $\%$ of dry matter yields).

\begin{tabular}{|c|c|c|c|c|c|}
\hline & \multicolumn{2}{|c|}{ Peat soils } & \multicolumn{3}{|c|}{ Sandy soils } \\
\hline & New ley & Old ley & Pasture & Old ley & New ley \\
\hline 1998 & $\begin{array}{l}P . \text { pratense } \\
\text { sown }\end{array}$ & $\begin{array}{l}\text { P. pratense } \\
(66 \%)\end{array}$ & $\begin{array}{l}\text { A. capillaris } \\
(61 \%), \\
\text { P. pratensis } \\
(29 \%)\end{array}$ & $\begin{array}{l}\text { P. pratense } \\
(75 \%), \\
\text { E. repens } \\
(17 \%)\end{array}$ & $\begin{array}{l}\text { P. pratense } \\
\text { sown }\end{array}$ \\
\hline 1999 & $\begin{array}{l}\text { P. pratense } \\
(90 \%)\end{array}$ & $\begin{array}{l}\text { P. pratense } \\
(65 \%)\end{array}$ & $\begin{array}{l}\text { A. capillaris } \\
(68 \%), \\
\text { P. pratensis } \\
(18 \%)\end{array}$ & $\begin{array}{l}\text { P. pratense } \\
(64 \%), \\
\text { E. repens } \\
(26 \%)\end{array}$ & $\begin{array}{l}P . \text { pratense } \\
(96 \%)\end{array}$ \\
\hline 2000 & $\begin{array}{l}\text { P. pratense } \\
(70 \%)\end{array}$ & $\begin{array}{l}\text { P. pratense } \\
(42 \%)\end{array}$ & $\begin{array}{l}\text { A. capillaris } \\
(70 \%) \text {, } \\
\text { P. pratensis } \\
(16 \%)\end{array}$ & $\begin{array}{l}\text { P. pratense } \\
(45 \%), \\
\text { E. repens } \\
(35 \%)\end{array}$ & $\begin{array}{l}P . \text { pratense } \\
(86 \%)\end{array}$ \\
\hline
\end{tabular}

$0.6 \mathrm{~mm}$ ), and classified as Aquic Cryumbrept according to Soil Survey Staff (1975). In the fields with peat, the degree of decomposition was moderate to strong (von Post H5-H8), and the soils were classified as Hemic Terric Borosaprists according to Soil Survey Staff (1975). In the field with established ley, the peat layer was 40-100 $\mathrm{cm}$ deep. The drainage with construction of a graded surface towards open ditches had caused a partial mixing of mineral soil from below the peat layer into the plough layer. In the field with new ley, the peat soil was $80-120 \mathrm{~cm}$ deep and was drained by plastic pipes.

Traffic regimes and fertilizer levels had no significant effects on the botanical composition. At the start of the experiment all fields with leys were dominated by timothy (Phleum pratense L.) (Table 2). The old pasture was dominated by common bent (Agrostis capillaris L.) and smooth meadow grass (Poa pratensis L.). In the established leys on sandy soil (sown in 1996) the content of couch grass (Elytrigia repens (L.) Nevski) increased rapidly during the experimental years.

\section{Treatments}

Five experimental fields were established in spring 1998 at Vågønes research station, Bodø, northern Norway $\left(67^{\circ} 17^{\prime} \mathrm{N}, 14^{\circ} 26^{\prime} \mathrm{E}\right)$. Three fields had established grass swards: an old pasture seeded in 1982 on a sandy soil, one ley seeded in 1996 on a sandy soil and one seeded in 1994 on a peat soil with graded surface towards open ditches. The traffic and fertilization treatments were applied in these three fields during the seasons 1998-2000. Two fields, one on a sandy soil and one on a peat soil, were seeded with timothy ( $P$. pratense) in spring 1998, and $30 \mathrm{Mg} \mathrm{ha}^{-1}$ aerated cattle slurry was applied before sowing. Experimental fertilization and traffic treatments were applied in 1999 and 2000 in the two fields sown in 1998.

Treatments with three replicates were as follows:

A. Main plot: Traffic intensity at harvest

- No tractor, NT

- Light tractor (axle load 2.8 Mg) with forage harvester and trailer, LTFH

- Light tractor (axle load $2.8 \mathrm{Mg}$ ) with twostep harvesting and round baling, LTRB

- Medium tractor (axle load 4.3 Mg) with forage harvester and trailer, MTFH

- Medium tractor (axle load 4.3 Mg) with two-step harvesting and round baling, MTRB 
Volden, B. et al. Effects of traffic and fertilization on grassland yields

B. Split-plot: $\mathrm{N}$ fertilization

- $\mathrm{N} 80 \mathrm{~kg} \mathrm{ha}^{-1}$ in spring and $\mathrm{N} 40 \mathrm{~kg} \mathrm{ha} \mathrm{h}^{-1}$ after first cut

- $\mathrm{N} 120 \mathrm{~kg} \mathrm{ha}^{-1}$ in spring and N $60 \mathrm{~kg} \mathrm{ha}^{-1}$ after first cut

- $\mathrm{N} 160 \mathrm{~kg} \mathrm{ha}^{-1}$ in spring and N $80 \mathrm{~kg} \mathrm{ha}^{-1}$ after first cut

In May, each spring $20 \mathrm{Mg} \mathrm{ha}^{-1}$ aerated cattle slurry was applied to all plots. In addition, NPK fertilizer $(18 \% \mathrm{~N}-3 \% \mathrm{P}-15 \% \mathrm{~K})$ was applied in spring and after the first cut giving three levels of nitrogen application. The middle fertilization level ( $180 \mathrm{~kg} \mathrm{ha}^{-1}$ per season) is recommended on mineral and peat soils for farming practice with two cuts in this region of northern Norway. The first cut was taken in early July, and the second cut was taken in September (Table 3).

Traffic on the plots was performed by simulating the equipment for fertilizing and harvesting used in common farming practice with the two mechanisation lines:

- NPK fertilizer was distributed by a light experimental spreader (Varo). A three point linked centrifugal distributor was simulated by attaching a $0.4 \mathrm{Mg}$ weight (half load) to the three point linkage of light $(2.8 \mathrm{Mg})$ and medium $(4.3 \mathrm{Mg})$ tractors. One tour across the plots was driven with traffic in spring and after first cut.

- Cattle slurry was spread on the plots by a liquid manure spreader alongside the fields. On the MTFH and MTRB plots this was simulated by passing across once in spring with a medium-sized tractor and trailer with $3000 \mathrm{~kg}$ total weight (tyres: $400 \mathrm{~mm}$ breadth). Light

Table 3. Dates of spring fertilizer application and harvesting times in 1998-2000.

\begin{tabular}{llll}
\hline Year & $\begin{array}{l}\text { Spring fertilizer } \\
\text { application }\end{array}$ & 1st cut & 2nd cut \\
\hline 1998 & 20-22 May & 7 Jul & 7 Sep \\
1999 & 18 May & 6-8 Jul & $\begin{array}{l}\text { 15-17 Sep } \\
2000\end{array}$ \\
\hline
\end{tabular}

traffic (LTFH and LTRB) was not simulated, as the slurry would in this system be spread by irrigation.

- The forage harvester simulated had $1.35 \mathrm{~m}$ broad cutting width. Two-step harvesting was simulated using disc harvester (5 discs, $2.5 \mathrm{~m}$ ) and round bale press. The simulation of light traffic was performed by a Ford 4600 tractor with tyres; $190 \mathrm{~mm}$ (in front) and $345 \mathrm{~mm}$ breadth (rear) and trailer with $1.5 \mathrm{Mg}$ total weight (half load). Medium traffic was simulated by a Valmet 405 tractor with tyres; $315 \mathrm{~mm}$ breadth (in front) and $430 \mathrm{~mm}$ breadth (rear) and trailer with $2.5 \mathrm{Mg}$ total weight.

Forage harvesting was simulated by passing the plot at $95 \mathrm{~cm}$ sideways distance for LTFH, and at $80 \mathrm{~cm}$ sideways distance for MTFH. At the second cut the wheels tracks were displaced sideways compared to the first cut, $35 \mathrm{~cm}$ for LTFH and $40 \mathrm{~cm}$ for MTFH. In the two-step system (LTRB and MTRB) there were two passes in same tracks at each harvest at a distance of $230 \mathrm{~cm}$. The traffic was concentrated to these tracks all years. The difference in wheel track cover by the harvesting traffic simulation is illustrated by Figure 1a (forage harvester) and Figure 1b (two-step harvesting).

The trailer used was the same for simulation of slurry spreading, and for light and medium harvesting. At light load the tyre pressure was $110 \mathrm{kPa}$ and the pressure was $170 \mathrm{kPa}$ at medium load. This was calculated to correspond to maximum $20 \%$ deformation of the tyres at full load for a small and medium trailer.

\section{Yield measurements}

All plots were cut twice each year at a 5-6 cm stubble height with a Haldrup 1500 plot harvester (load $1.2 \mathrm{Mg}$ ). Dry matter (DM) yields were measured after drying yield samples $\left(60^{\circ} \mathrm{C}\right.$, $48 \mathrm{~h}$ ). Yield measurements in wheel tracks were carried out in 2000 on the NT, LTRB and MTRB treatments in the fields on peat soils and in the 
Vol. 11 (2002): 219-231.

a)

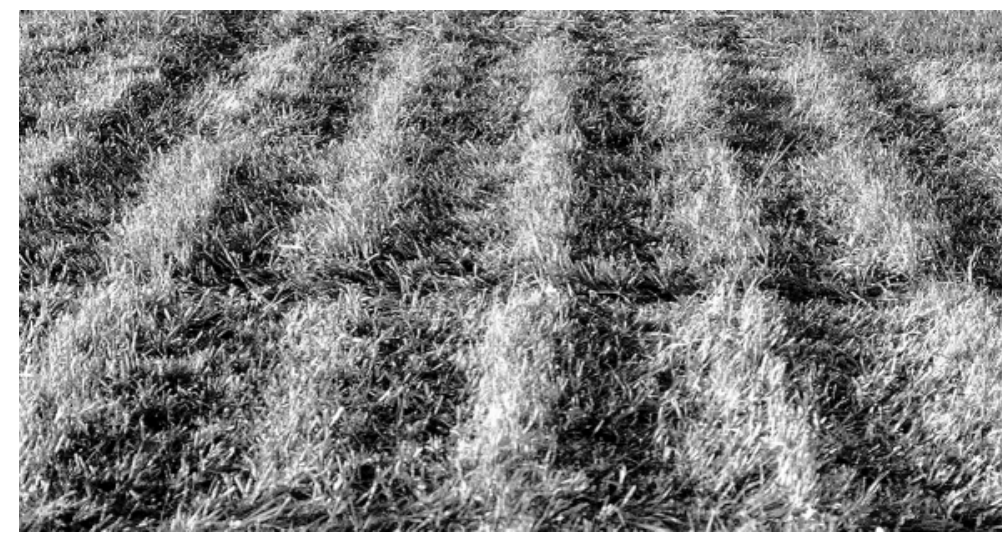

Fig. 1. Simulation of harvesting traffic with medium heavy tractor and trailer. a) Forage harvester. b) Two-step harvesting. Photo after 2 nd cut, 15 September 2000 at peat soil, 2nd year ley (Photos: B. Volden).

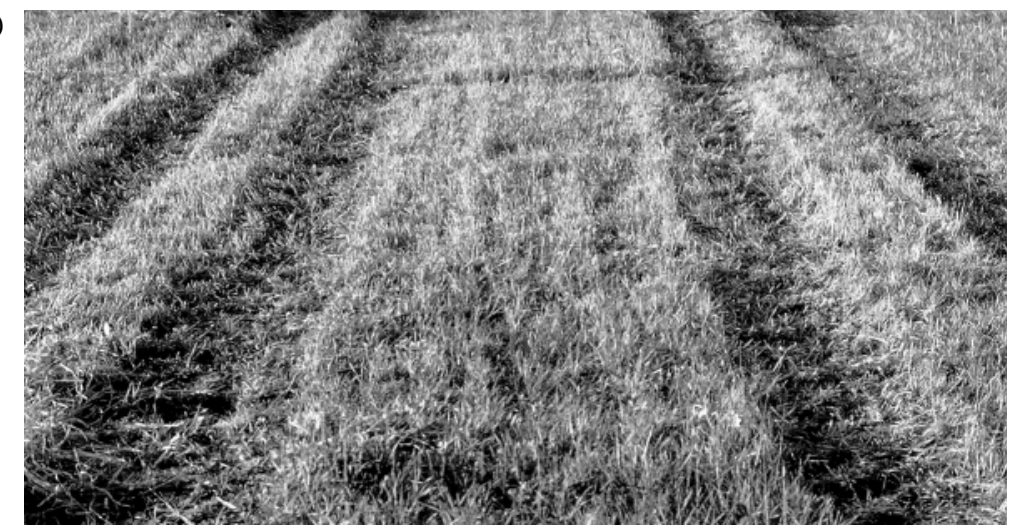

new ley on the sandy soil. The yields were recorded at first and second cut with a frame of $25 \mathrm{~cm} \times 100 \mathrm{~cm}$ in these tracks. As these yield measurements were rather laborious, they were conducted on two replicates only.

\section{Weather and climate}

Bod $\varnothing$ has a mean annual air temperature of $4.3^{\circ} \mathrm{C}$, and of $12.1^{\circ} \mathrm{C}$ in the period June-August (Aune 1993). Mean annual precipitation in Bodø is $1020 \mathrm{~mm}$, and around $50 \mathrm{~mm}$ per month during April-June. In July-August, the monthly precipitation is $90 \mathrm{~mm}$ (Førland 1993) (Table 4). During the experimental period, there were no problems related to ice cover on soil surface in the winter period, and no problems with winter damage on the grassland. Monthly air tempera- ture and precipitation in the growing season in the experimental period is shown in Table 4.

\section{Soil analyses}

Intact soil cores (volume $100 \mathrm{~cm}^{3}$, diameter $5.8 \mathrm{~cm}$ ) for physical analyses (three soil cores for each layer) were collected from two replicates for each harvesting treatment in all fields in October 2000. Pore size distribution was measured using ceramic pressure plates (Richards 1947, 1948). Water content was measured at saturation, $-0.5,-2,-5,-10$ and $-100 \mathrm{kPa}$ water potential. Bulk density was calculated after the soil had been dried at $105^{\circ} \mathrm{C}$. Air-filled porosity was defined as the difference between total porosity and water content at $-10 \mathrm{kPa}$. Soil moisture was examined at traffic time (first and 
Volden, B. et al. Effects of traffic and fertilization on grassland yields

Table 4. Precipitation and temperatures during the growing seasons 1998-2000 (Vågønes Research Station, Bodø), and normals (1961-90) at Bodø [Aune (1993) and Førland (1993)].

\begin{tabular}{|c|c|c|c|c|c|c|c|c|c|c|c|c|}
\hline \multirow[t]{2}{*}{ Year } & \multicolumn{6}{|c|}{ Precipitation, mm } & \multicolumn{6}{|c|}{ Temperature, ${ }^{\circ} \mathrm{C}$} \\
\hline & Apr & May & Jun & Jul & Aug & Sep & Apr & May & Jun & Jul & Aug & Sep \\
\hline 1998 & 28 & 117 & 53 & 68 & 70 & 89 & 2.2 & 5.8 & 11.8 & 15.1 & 12.9 & 10.4 \\
\hline 1999 & 80 & 82 & 76 & 132 & 78 & 88 & 3.7 & 6.7 & 11.8 & 12.0 & 10.6 & 12.1 \\
\hline 2000 & 73 & 88 & 106 & 28 & 106 & 115 & 2.3 & 7.8 & 9.0 & 13.0 & 11.3 & 10.1 \\
\hline Normal & 52 & 46 & 54 & 92 & 88 & 123 & 2.5 & 7.2 & 10.4 & 12.5 & 12.3 & 9.0 \\
\hline
\end{tabular}

second cut) on all experimental fields in 1999 and 2000, representing the actual soil moisture before traffic started. Composite soil samples (12-15 sub samples), representing each replicate, were taken from the plough layer $(0-20 \mathrm{~cm})$, weighed and air dried at $105^{\circ} \mathrm{C}$. Soil moisture on volume basis was calculated by using the measured soil moisture results and bulk densities.

\section{Statistical analyses}

Analyses of variance (ANOVA) were performed according to the split plot factorial design to test the effects on yields. Significance level of P < 0.05 was used. Separate analyses were carried out for sandy soils and peat soils. The two fields, which were experimentally treated and harvested only in 1999 and 2000, were computed as missing data (least squares technique) in 1998 when grouping after soil type. The Fisher's leastsignificant-differences (LSD) test was used for multiple comparisons. Influence of the tractor treatments on soil physical properties was tested by means of ANOVA with two replicates.

\section{Results}

\section{Water content and soil properties at traffic time}

At traffic time (1st and 2nd cut) the volumetric water content in the plough layer was lower in the sandy soils than in the peat soils. In the sandy soils, the moisture in the plough layer was close to field capacity $(-100 \mathrm{kPa}$ water potential). The water content in the plough layer of the peat soils was between or close to -2 and $-10 \mathrm{kPa}$ water potential (Table 5). The peat soil with graded surface (new leys) was drier than the pipe drained peat soil (established leys), especially in 2000.

\section{Effects of traffic on DM yields}

The MTRB treatment had significantly lower DM yields than the NT and LTFH treatments, on average of the three fields on sandy soils (Table 6). In the peat soils, all treatments with traffic had lower yield than the NT treatment (Table 7). The medium weight equipment caused larger yield loss than the light equipment, and there was no significant difference between the forage harvester system and two-step harvesting with round baling.

\section{Effects of fertilization levels on DM yields}

Fertilizer application above $\mathrm{N} 120 \mathrm{~kg} \mathrm{ha}^{-1}$ significantly increased DM yields both on mineral soils and peat soils (Tables 7 and 8). Nevertheless, the increments in yield were rather small, only $15-16 \%$ after doubling the fertilization. In the old pasture field, there was no yield increase for the largest dose of fertilizer, while the other experiments on mineral soil showed significant or nearly significant increase also at this level (Table 8). 
Vol. 11 (2002): 219-231.

Table 5. Volumetric water content in topsoil (0-20 cm) at traffic time (mean of 1st and 2nd cut in 1999 and 2000), and water content at $-2 \mathrm{kPa}$ and $-10 \mathrm{kPa}$ water potential.

\begin{tabular}{|c|c|c|c|c|c|}
\hline \multirow[t]{3}{*}{ Experiment } & \multirow[t]{3}{*}{ Year } & \multicolumn{4}{|c|}{ Water content, $\mathrm{m}^{3} \mathrm{~m}^{-3}$} \\
\hline & & \multicolumn{2}{|c|}{ At traffic time } & \multirow{2}{*}{$\begin{array}{c}\text { At }-2 \\
\mathrm{kPa}\end{array}$} & \multirow{2}{*}{$\begin{array}{c}\text { At }-10 \\
\mathrm{kPa}\end{array}$} \\
\hline & & Average & Range & & \\
\hline \multirow{2}{*}{$\begin{array}{l}\text { Pasture, seeded 1982, } \\
\text { sandy soil }\end{array}$} & 1999 & 0.34 & $0.30-0.38$ & \multirow[t]{2}{*}{0.44} & \multirow[t]{2}{*}{0.28} \\
\hline & 2000 & 0.26 & $0.23-0.29$ & & \\
\hline \multirow{2}{*}{$\begin{array}{l}\text { Established ley, seeded 1996, } \\
\text { sandy soil }\end{array}$} & 1999 & 0.26 & $0.24-0.27$ & \multirow[t]{2}{*}{0.42} & \multirow[t]{2}{*}{0.29} \\
\hline & 2000 & 0.22 & $0.20-0.24$ & & \\
\hline \multirow{2}{*}{$\begin{array}{l}\text { New ley, seeded } 1998, \\
\text { sandy soil }\end{array}$} & 1999 & 0.30 & $0.28-0.33$ & \multirow[t]{2}{*}{0.43} & \multirow[t]{2}{*}{0.30} \\
\hline & 2000 & 0.28 & $0.24-0.33$ & & \\
\hline \multirow{2}{*}{$\begin{array}{l}\text { Established ley, seeded 1994, } \\
\text { peat soil }\end{array}$} & 1999 & 0.69 & $0.66-0.72$ & \multirow[t]{2}{*}{0.72} & \multirow[t]{2}{*}{0.67} \\
\hline & 2000 & 0.53 & $0.52-0.53$ & & \\
\hline \multirow{2}{*}{$\begin{array}{l}\text { New ley, seeded } 1998, \\
\text { peat soil }\end{array}$} & 1999 & 0.76 & $0.73-0.79$ & \multirow[t]{2}{*}{0.78} & \multirow[t]{2}{*}{0.72} \\
\hline & 2000 & 0.76 & $0.72-0.80$ & & \\
\hline
\end{tabular}

Table 6. Dry matter (DM) yields $\left(\mathrm{kg} \mathrm{ha}^{-1}\right)$ in three experiments on sandy soils after different traffic treatments. Average of three years (new ley, two years).

\begin{tabular}{|c|c|c|c|c|c|c|}
\hline \multirow[t]{3}{*}{ Tractor } & \multirow{3}{*}{$\begin{array}{l}\text { Treatment } \\
\text { code }\end{array}$} & \multicolumn{3}{|c|}{ Experiment } & \multicolumn{2}{|c|}{ Average } \\
\hline & & Established ley & New ley & Old pasture & & \multirow{2}{*}{$\begin{array}{l}\text { Rel. } \\
\text { yield }\end{array}$} \\
\hline & & \multicolumn{4}{|c|}{$--------\mathrm{DM}, \mathrm{kg} \mathrm{ha}^{-1}-------$} & \\
\hline No tractor & NT & 7980 & 9790 & 6880 & 8020 & 100 \\
\hline Light tractor & $\mathrm{LTFH}^{1}$ & 7850 & 9630 & 6810 & 7900 & 99 \\
\hline Light tractor & $\mathrm{LTRB}^{2}$ & 7890 & 9620 & 6250 & 7700 & 96 \\
\hline Medium tractor & $\mathrm{MTFH}^{1}$ & 7970 & 9360 & 6600 & 7810 & 97 \\
\hline Medium tractor & MTRB $^{2}$ & 7700 & 9270 & 6080 & 7480 & 93 \\
\hline $\mathrm{LSD}_{0.05}$ & & ns & ns & ns & 333 & \\
\hline
\end{tabular}

$\mathrm{LSD}_{0.05}=$ Least significant difference at $\mathrm{P}<0.05 ; \mathrm{ns}=$ not significant

${ }^{1} \mathrm{FH}=$ forage harvester and trailer

$2 \mathrm{RB}=$ two-step harvesting and round baling

\section{Interaction between traffic treatments and fertilization}

On the peat soils, there was a significant interaction between traffic and fertilization on DM yields (Table 7). Increased fertilizer application from $\mathrm{N} 120$ to $180 \mathrm{~kg} \mathrm{ha}^{-1}$ gave high yield increase, for the NT, LTFH and LTRB treatments. Further increase from N 180 to $240 \mathrm{~kg} \mathrm{ha}^{-1}$ gave much less yield increase. The yield response with the MTFH and MTRB treatments was low when $\mathrm{N}$-fertilization increased from N 120 to $180 \mathrm{~kg}$ $\mathrm{ha}^{-1}$. However, a further increase in fertilizer from $\mathrm{N} 180$ to $240 \mathrm{~kg} \mathrm{ha}^{-1}$ gave a large yield increase. For the treatments with light traffic (LTFH and LTRB), the yields at N $180 \mathrm{~kg} \mathrm{ha}^{-1}$ were approximately equal to the yields of the MTFH and MTRB treatments at N $240 \mathrm{~kg} \mathrm{ha}^{-1}$ (Table 7). There was no significant interaction between traffic and fertilization on the sandy 
Volden, B. et al. Effects of traffic and fertilization on grassland yields

Table 7. Dry matter yields $\left(\mathrm{kg} \mathrm{ha}^{-1}\right)$ in two experiments on peat soils. Average of three years (new ley, two years).

\begin{tabular}{|c|c|c|c|c|c|c|}
\hline \multirow[t]{2}{*}{ Tractor } & \multirow{2}{*}{$\begin{array}{l}\text { Treatment } \\
\text { code }\end{array}$} & \multicolumn{3}{|c|}{ Fertilization level, $\mathrm{N} \mathrm{kg} \mathrm{ha-}$} & \multicolumn{2}{|c|}{ Average, traffic } \\
\hline & & 120 & 180 & 240 & DM kg ha ${ }^{-1}$ & Rel. yield \\
\hline No tractor & NT & 8300 & 9340 & 9630 & 9090 & 100 \\
\hline Light tractor & LTFH $^{1}$ & 7400 & 8480 & 8550 & 8140 & 90 \\
\hline Light tractor & $\mathrm{LTRB}^{2}$ & 7760 & 8760 & 8780 & 8430 & 93 \\
\hline Medium tractor & MTFH $^{1}$ & 7070 & 7390 & 8400 & 7620 & 84 \\
\hline Medium tractor & MTRB $^{2}$ & 7560 & 7600 & 8400 & 7850 & 86 \\
\hline Average, fertilization & & 7620 & 8310 & 8750 & & \\
\hline
\end{tabular}

$\mathrm{LSD}_{0.05}=$ Least significant difference at $\mathrm{P}<0.05$

${ }^{1} \mathrm{FH}=$ forage harvester and trailer

${ }^{2} \mathrm{RB}=$ two-step harvesting and round baling

Table 8. Yields in three experiments on sandy soils after different fertilization levels, DM $\mathrm{kg} \mathrm{ha}^{-1}$. Average of three years (new ley, two years).

\begin{tabular}{ccccc}
\hline $\begin{array}{c}\text { Nitrogen fertilization level } \\
\text { N kg ha }\end{array}$ & \multicolumn{3}{c}{ Experimental field type } \\
\cline { 2 - 4 } & Established ley & New ley & Old pasture & Average \\
\hline 120 & 7280 & 8860 & 5960 & 7170 \\
180 & 7950 & 9530 & 6740 & 7890 \\
240 & 8400 & 10230 & 6860 & 8290 \\
$\mathrm{LSD}_{0.05}$ & 349 & 757 & 714 & 363 \\
\hline
\end{tabular}

$\mathrm{LSD}_{0.05}=$ Least significant difference at $\mathrm{P}<0.05$

soils probably due to the limited effect of traffic treatments in these soils.

\section{DM yields in tracks}

The yield reduction in the tracks was significant in the peat soils (Table 9). In these soils, the heaviest traffic load also gave significantly less yield in the tracks compared to light traffic load. With the highest traffic load and application of N $240 \mathrm{~kg} \mathrm{ha}^{-1}$ the yield in the tracks was less than in uncompacted soil where $\mathrm{N} 120 \mathrm{~kg} \mathrm{ha}^{-1}$ was applied. The yields in tracks with $\mathrm{N} 180 \mathrm{~kg}$ $\mathrm{ha}^{-1}$ were approximately equal to the yields of uncompacted soil where $\mathrm{N} 120 \mathrm{~kg} \mathrm{ha}^{-1}$ was applied. In the sandy soils, the yield in the tracks after medium or light traffic was 71 to $75 \%$ of the yield in uncompacted soil, but the difference was not statistically significant.

\section{Effects of traffic treatments on soil physical parameters}

No statistically significant differences in bulk density and total porosity in the plough layer were measured between the traffic treatments. The only statistically significant effect of the traffic treatments was decreased air-filled porosity $(-10 \mathrm{kPa}$ water potential) in the layer $1-5 \mathrm{~cm}$ of the peat soils (Table 10). Similarly, air-filled porosity $(-10 \mathrm{kPa}$ water potential) in the layer $1-5 \mathrm{~cm}$ in the sandy soil decreased by tractor traffic from $0.187 \mathrm{~m}^{3} \mathrm{~m}^{-3}$ in the NT treatment to $0.146 \mathrm{~m}^{3} \mathrm{~m}^{-3}$ in the MTRB treatment. The difference was not statistically significant because of lack of replicates. The bulk density of fields with the sandy soils was $1.28-1.32 \mathrm{Mg} \mathrm{m}^{-3}$ in the layer $1-5 \mathrm{~cm}$, and $1.35-1.37 \mathrm{Mg} \mathrm{m}^{-3}$ at $10-$ $14 \mathrm{~cm}$ depth. Bulk density of the peat soil with 
Vol. 11 (2002): 219-231.

Table 9. Yields in (tractor) wheel tracks. Registrations in three experiments in year 2000.

\begin{tabular}{|c|c|c|c|c|}
\hline \multirow[t]{2}{*}{ Tillage treatment } & \multirow{2}{*}{$\begin{array}{l}\text { Fertilization, } \\
\mathrm{N} \mathrm{kg} \mathrm{ha}^{-1}\end{array}$} & \multicolumn{3}{|c|}{ DM yield, kg ha ${ }^{-1}$} \\
\hline & & New ley, sand & $\begin{array}{c}\text { Established } \\
\text { ley, peat }\end{array}$ & New ley, peat \\
\hline $\begin{array}{l}\text { No traffic } \\
\text { (no tracks) }\end{array}$ & $\begin{array}{l}120 \\
180 \\
240\end{array}$ & $\begin{array}{r}9900 \\
9780 \\
10260\end{array}$ & $\begin{array}{r}8860 \\
9720 \\
12160\end{array}$ & $\begin{array}{l}10580 \\
13320 \\
15860\end{array}$ \\
\hline $\begin{array}{l}\text { Light tractor, } \\
\text { two-step harvesting }\end{array}$ & $\begin{array}{l}120 \\
180 \\
240\end{array}$ & $\begin{array}{l}6560 \\
7960 \\
7830\end{array}$ & $\begin{array}{ll}7 & 180 \\
9 & 140 \\
9 & 580\end{array}$ & $\begin{array}{r}8940 \\
10140 \\
11680\end{array}$ \\
\hline $\begin{array}{l}\text { Medium tractor, } \\
\text { two-step harvesting }\end{array}$ & $\begin{array}{l}120 \\
180 \\
240\end{array}$ & $\begin{array}{l}5760 \\
6640 \\
8640\end{array}$ & $\begin{array}{l}5180 \\
5780 \\
6480\end{array}$ & $\begin{array}{l}4560 \\
6920 \\
9620\end{array}$ \\
\hline $\mathrm{LSD}_{0.05}$ & & ns & 1100 & ns \\
\hline $\begin{array}{l}\text { No traffic }{ }^{1} \\
\text { Light, two-step }^{1} \\
\text { Medium, two-step }\end{array}$ & & $\begin{array}{l}9980 \\
7450 \\
7010\end{array}$ & $\begin{array}{r}10250 \\
8630 \\
5810\end{array}$ & $\begin{array}{r}13250 \\
10250 \\
7000\end{array}$ \\
\hline $\mathrm{LSD}_{0.05}$ & $\begin{array}{l}120^{2} \\
180^{2} \\
240^{2}\end{array}$ & $\begin{array}{cc} & n s \\
7 & 410 \\
8 & 130 \\
8 & 910\end{array}$ & $\begin{array}{r} \\
560 \\
7070 \\
8210 \\
9410\end{array}$ & $\begin{array}{r}261 \\
8030 \\
10090 \\
12390\end{array}$ \\
\hline $\mathrm{LSD}_{0.05}$ & & ns & 1500 & 1350 \\
\hline
\end{tabular}

$\mathrm{LSD}_{0.05}=$ Least significant difference at $\mathrm{P}<0.05$; $\mathrm{ns}=$ not significant

${ }^{1}$ Means are averaged of three traffic levels

${ }^{2}$ Means are averaged of three fertilization treatments

Table 10. Influence of traffic treatments on porosity of the plough layer.

\begin{tabular}{|c|c|c|c|c|c|}
\hline \multirow[t]{2}{*}{ Soil depth, cm } & \multirow[t]{2}{*}{ Treatment code } & \multicolumn{2}{|c|}{ Total porosity, $\mathrm{m}^{3} \mathrm{~m}^{-3}$} & \multicolumn{2}{|c|}{ Air-filled porosity, $\mathrm{m}^{3} \mathrm{~m}^{-3}$} \\
\hline & & Sandy soils & Peat soils & Sandy soils & Peat soils \\
\hline $1-5$ & NT & 0.475 & 0.800 & 0.187 & 0.136 \\
\hline $1-5$ & LTFH & 0.470 & 0.811 & 0.189 & 0.082 \\
\hline $1-5$ & MTFH & 0.459 & 0.748 & 0.155 & 0.093 \\
\hline $1-5$ & LTRB & 0.463 & 0.803 & 0.170 & 0.099 \\
\hline $1-5$ & MTRB & 0.475 & 0.798 & 0.146 & 0.075 \\
\hline $\mathrm{LSD}_{0.05}$ & & ns & ns & ns & 0.041 \\
\hline $10-14$ & NT & 0.447 & 0.796 & 0.177 & 0.101 \\
\hline $10-14$ & LTFH & 0.453 & 0.809 & 0.186 & 0.073 \\
\hline $10-14$ & MTFH & 0.451 & 0.739 & 0.163 & 0.083 \\
\hline $10-14$ & LTRB & 0.465 & 0.777 & 0.173 & 0.079 \\
\hline $10-14$ & MTRB & 0.444 & 0.801 & 0.170 & 0.078 \\
\hline $\mathrm{LSD}_{0.05}$ & & ns & ns & ns & ns \\
\hline
\end{tabular}

$\mathrm{LSD}_{0.05}=$ Least significant difference at $\mathrm{P}<0.05 ; \mathrm{ns}=$ not significant

$\mathrm{NT}=$ no tractor; $\mathrm{LTFH}=$ light tractor, forage harvester and trailer; $\mathrm{MTFH}=$ medium tractor, forage harvester and trailer; LTRB = light tractor, two-step harvesting and round baling; MTRB = medium tractor, two-step harvesting and round baling 
Volden, B. et al. Effects of traffic and fertilization on grassland yields

graded surface was $0.41 \mathrm{Mg} \mathrm{m}^{-3}$ in $1-5 \mathrm{~cm}$, and $0.47 \mathrm{Mg} \mathrm{m}^{-3}$ at $10-14 \mathrm{~cm}$ depth. The peat soil with plastic pipes had uniform bulk density in the plough layer, $0.34-0.35 \mathrm{Mg} \mathrm{m}^{-3}$.

\section{Discussion}

The effects of traffic on the yield of leys in these experiments were partly related to the moisture conditions in the soils. The well sorted sandy soils had a moisture content close to field capacity at the time of traffic. Such soils are resistant to light and medium soil compaction. Sandy soils with similar sorting are by Karlsson (1988) found to be suitable as root zone material for turf grass at sports fields. According to Douglas (1994), a large number of studies show that the largest yield loss occurs when compaction is carried out under wet conditions in spring. The same compaction on drier soil and with more developed plants may give less yield reduction. Zhezmer et al. (1990) found that the water content of peat soils was of great importance for the yield decrease due to compaction. Repeated passes with moderately heavy machinery could completely destroy the perennial grasses on wet peat soils, while more heavy and efficient agricultural machines could be used on drier peat soils without severe yield loss. Myhr and Njøs (1983) found no significant yield decrease due to compaction in fields with one annual cut on peat soils in northern Norway, while compaction caused decreased yields in fields with two cuts on peat soils. This is in accordance with the results at the first cut in these experiments, as the limited traffic in spring will give small damage directly on plants and as compaction of the soil.

The yields in all fields were relatively high at the basic level of fertilization, and the increase in yields due to fertilization was significant, but relatively small. The high yields may be related to good growth conditions without severe growth restrictions related to wet soils. In the compact- ed treatments of the peat soils, the air-filled porosity was less than $0.1 \mathrm{~m}^{3} \mathrm{~m}^{-3}$ (Table 10). The limit for sufficient aeration of different crops has been found to be in the range $0.08-0.12 \mathrm{~m}^{3} \mathrm{~m}^{-3}$ (Grable and Siemer 1968), and air-filled porosity $<0.1 \mathrm{~m}^{3} \mathrm{~m}^{-3}$ is characteristic of deficient aeration according to Grable (1971). Without compaction the air-filled porosity in the upper part of the plough layer was above the critical range. After trafficking the air-filled porosity was around the lower limit for satisfactory aeration according to Grable and Siemer (1968). In years when the peat soil is drier than field capacity $(-10 \mathrm{kPa}$ water potential) in large parts of the growing season, the decreased air-filled porosity due to compaction will be of less importance for the grass growth and yield since actual airfilled porosity will increase. This was the case for the peat soil with graded surface and open ditches. In the peat soil with plastic drainage pipes, the soil moisture in the plough layer was around field capacity or even wetter in periods, and soil compaction may cause the plants grown in this soil to suffer from poor aeration because of excessive wetness.

In the present investigation the tractor traffic treatments only caused significant reduction of air-filled porosity in the $1-5 \mathrm{~cm}$ layer of the peat soil. Sveistrup and Haraldsen (1997) found that tractor traffic did not always cause significant decreases in air-filled porosity in the plough layer of peat soils in northern Norway. The moisture conditions of the soil when traffic takes place, is of great importance for how strongly compaction reduces air-filled porosity. Both Myhr and Njøs (1983) and Sveistrup and Haraldsen (1997) found a difference in air-filled porosity between a no tractor and a tractor treatment, but no significant differences in air-filled porosity between treatments with different tractor loads. In an other investigation (Rasmussen and Møller 1981) increasing tractor loads increased bulk density and decreased air-filled porosity, whilst Douglas et al. (1992) found that reduced ground pressure gave decreased bulk density in the topsoil compared to conventional ground pressure. 
Vol. 11 (2002): 219-231.

The pasture field showed less response to the highest fertilizer rate than the fields with leys on mineral soils. This may be explained by the low $\mathrm{pH}$ and the botanical composition of the pasture field, which consisted of common bent and smooth meadow grass. Grassland dominated by common bent usually has a lower yield than leys dominated by timothy (Nesheim 1986).

The small yield response of compaction on the sandy soils correspond with Wopereis et al. (1990), who found no significant effect of compaction when nitrogen application was $\mathrm{N} 200 \mathrm{~kg}$ $\mathrm{ha}^{-1}$ or more. Without nitrogen input on sandy soils, Wopereis et al. (1990) found that both normal and heavy compaction caused significant yield loss. The variable response to increased fertilizer application on peat soils trafficked by light and medium weight tractors suggests that different degrees of compaction may affect the plants above and below soil surface differently. Heavy traffic may have decreased the ability of the plants to utilize applied plant nutrients on the peat soils due to direct damage of the plants. Rasmussen and Møller (1981) found that yield loss due to compaction was much greater than could be explained by changes in soil physical conditions. Crushing of plant material under the tractor wheels may be an important reason for yield loss in grassland. The decreased yields and low effect of fertilizer in the wheel tracks both on sandy soils and peat soils in the present investigation, showed that tractor wheels passing affected nutrient uptake and plant growth. Although some farmers compensate with extra fertilizer for compaction by heavy agricultural machinery, Tveitnes and Njøs (1974) and Douglas and Crawford (1993) have shown that additional nitrogen cannot fully compensate for the yield loss caused by compaction. Using the recommended fertilization level $\mathrm{N} 180 \mathrm{~kg} \mathrm{ha}^{-1}$ or $\mathrm{N}$ $120 \mathrm{~kg} \mathrm{ha}^{-1}$ on peat soils the present investigation shows that additional nitrogen supply of $\mathrm{N}$ $60 \mathrm{~kg} \mathrm{ha}^{-1}$ is needed if the same yield should be obtained using medium heavy machinery instead of light tractors. In the systems with medium heavy machinery, this additional $\mathrm{N}$ is not utilized by the plants, but may be lost as leaching or due to denitrification because of poor aeration (Douglas and Crawford 1998). The results therefore indicates that use of lighter machines on peat soils will give lower fertilizer costs for the farmers, and decrease the risk of increased leaching and other losses of plant nutrients from the soil.

The results do not show any significant differences in yield between the forage harvesting system and the two-step harvest system with round baling on the peat soils, while the twostep harvest system and medium tractor load gave smallest yield on sandy soils. Due to repeated passes in the same tracks in the two-step harvest system a smaller percentage of the surface area was covered by tracks, while in the forage harvesting system the tracks were more evenly distributed (see Figs. 1a and 1b). The results indicate that the load of the machinery was more important than the harvesting system on peat soils. The poor yields in the two-step harvest system with medium load on the sandy soils was a result of poor growth and response to fertilizer $\mathrm{N}$ in the tracks, and small negative effects of the more evenly distributed tracks in the forage harvesting system. Accumulation of soil compaction effects year by year was found in peat soils in the study of Haraldsen et al. (1995), who carried out investigations during a five-year period. It is therefore possible that the experimental period of three years in the present investigation is too short for development of significant differences in yield between the different harvesting systems on peat soils.

\section{Conclusions}

In field experiments in northern Norway, the effects of agricultural machinery varied between sandy soils and peat soils. On sandy soils there was no significant difference in yields or in soil physical properties in the plough layer between traffic-free and forage harvesting systems. On the peat soils, all traffic treatments gave lower yields than no traffic. Use of the heaviest equip- 
Volden, B. et al. Effects of traffic and fertilization on grassland yields

ment (tractor $4.3 \mathrm{Mg}$ ) gave the greatest yield reduction. When light machines (tractor $2.8 \mathrm{Mg}$ ) were used, there was a significant yield increase from $\mathrm{N} 120$ to $180 \mathrm{~kg} \mathrm{ha}^{-1}$, but no significant yield increase at higher nitrogen levels. When the heaviest machines were used, N $60 \mathrm{~kg} \mathrm{ha}^{-1}$, additional nitrogen was necessary in order to obtain the same yield as with the use of light machines. The results showed that the weight of the agricultural machines was more important for decrease in yield level than the harvesting system on peat soils.

These results have important implications for practical farming. Farmers on sandy soils with low organic matter content will experience lim- ited benefit by the use of light tractors $(<3.0$ $\mathrm{Mg}$ ) compared to moderately heavy tractors (4.0-4.5 Mg). Farmers on peat soils, on the other hand, will have better utilization of applied fertilizer if they use light machines compared to moderately heavy machines. Use of light machines on peat soils may therefore have a positive influence on the farmers' economy and be the best practice in relation to the environment.

Acknowledgements. The paper is an outcome of the project "Yield stability of grassland in northern Norway" which has been supported by the Research Council of Norway (Grant no. 119043/110). We thank Dr. Hugh Riley for correcting the language and giving comments on the manuscript.

\section{References}

Aune, B. 1993. Air temperature normals, normal period 1961-1990. Det norske meteorologiske institutt. Rapport 02/93 Klima. $63 \mathrm{p}$.

Douglas, J.T. 1994. Responses of perennial forage crops to soil compaction. In: Soane, B.D. \& Ouwerkerk, C. van (eds.). Soil Compaction in Crop Production. Elsevier Science B.V. p. 343-364.

Douglas, J.T., Campbell, D.J. \& Crawford, C.E. 1992. Soil and crop responses to conventional, reduced ground pressure and zero traffic systems for grass silage production. Soil \& Tillage Research 24: 421-439.

Douglas, J.T. \& Crawford, C.E. 1993. The response of a ryegrass sward to wheel traffic and applied nitrogen. Grass and Forage Science 48: 91-100.

Douglas, J.T. \& Crawford, C.E. 1998. Soil compaction effects on utilization of nitrogen from livestock slurry applied to grassland. Grass and Forage Science 53: 31-40.

FAO 1990. Guidelines for Soil Description. 3rd edition. FAO, Rome. $70 \mathrm{p}$.

Førland, E. 1993. Precipitation normals, normal period 1961-1990. Det norske meterorologiske institutt. Rapport 39/93 Klima. 63 p.

Grable, A.R. 1971. Effects of compaction on content and transmission of air in soils. In: Barnes, K.K. et al. (eds.). Compaction of Agricultural Soils. American Society of Agricultural Engineers, St. Joseph, MI, USA. p. 154-164.

Grable, A.R. \& Siemer, E.G. 1968. Effects of bulk density, aggregate size, and soil water suction on oxygen diffusion, redox potentials and elongation of corn roots. Soil Society of America Proceedings 32: 180186.
Håkansson, I., McAfee, M. \& Gunnarsson, S. 1990. Effects of traffic during harvest on yield of grass leys. Results from field trials on 24 Swedish sites. Swedish University of Agricultural Sciences, Uppsala. Reports from the Division of Soil Management 78. 41 p.

Haraldsen, T.K. \& Grønlund, A. 1989. Soil survey at Vågønes Agricultural Research Station, Northern Norway. Norsk landbruksforsking Supplement 6. 59 p. (in Norwegian, with English summary).

Haraldsen, T.K. \& Sveistrup, T.E. 1996. Influence of cattle slurry application and soil faunal activity on infiltration in soils from northern Norway. Norwegian Journal of Agricultural Sciences 10: 43-54.

Haraldsen, T.K., Sveistrup, T.E., Lindberg, K. \& Johansen, T.J. 1995. Soil compaction and drainage systems of peat soils in northern Norway. Effects on yields and botanical composition. Norsk landbruksforsking 9: 11-28. (in Norwegian, with English summary).

Karlsson, I.M. 1988. Soil construction, drainage and maintenance for Swedish grassed parks and sports fields. Acta Agriculturæ Scandinavica Supplementum 26. $99 \mathrm{p}$.

Myhr, K. \& Njøs, A. 1983. Effects of tractor traffic, number of cuts and liming on yields and soil physical properties in Norwegian grasslands. Meldinger fra Norges landbrukshøgskole 62, 1: 1-14. (in Norwegian, with English summary).

Nesheim, L. 1986. A grassland survey in Nordland, North Norway. III. Feed quality parameters and yield. Meldinger fra Norges landbrukshøgskole 65, 20: 149.

Rasmussen, K.J. \& Møller, E. 1981. Regrowth after prewilting of grassland crops. II. Soil compaction in con- 


\section{AGRICULTURAL AND FOOD SCIENCE IN FINLAND}

Vol. 11 (2002): 219-231.

nection with harvest and transport. Tidsskrift for Planteavl 85: 59-71. (in Danish, with English summary).

Richards, L.A. 1947. Pressure-membrane apparatus, construction and use. Agricultural Engineering 28: 451-454, 460.

Richards, L.A. 1948. Porous plate apparatus for measuring moisture retention and transmission by soils. Soil Science 66: 105-110.

Soil Survey Staff 1975. Soil Taxonomy. A Basic System of Soil Classification for Making and Interpreting Soil Surveys. USDA Agriculture Handbook 436. 754 p.

Sveistrup, T.E. \& Haraldsen, T.K. 1997. Effects of soil compaction on root development of perennial grass leys in northern Norway. Grass and Forage Science 52: 381-387.

Thomas, R. \& Evans, C. 1975. Field experience on grassland soils. In: Soil Physical Conditions and Crop Production. HMSO, London, U.K., MAFF, Technical Bulletin 29. p. 112-124.
Tveitnes, S. \& Njøs, A. 1974. Soil compaction problems on grassland in West Norway. Forskning og forsøk $i$ landbruket 24: 271-284. (in Norwegian, with English summary).

Wopereis, F.A., Spek, T., Schoonderbeek, D. \& Everts, H. 1990. Influence of soil compaction on rooting patterns and dry matter production on sandy soils. In: Gáborcic, N. et al. (eds.). Soil-Grassland-Animal Relationships. Proceedings of the 13th General Meeting of the European Grassland Federation, Banská Bystrica, Czechoslovakia, 25-29 June 1990. Vol. 1. p. 184-189.

Zhezmer, N.V., Zotov, A.A., Dedaev, G.A., Shevtov, A.V. \& Kozlov, V.V. 1990. Effects of agricultural machinery on the grassland productivity and soil conditions. In: Gáborcic, N. et al. (eds.). Soil-Grassland-Animal Relationships. Proceedings of the 13th General Meeting of the European Grassland Federation, Banská Bystrica, Czechoslovakia, 25-29 June 1990. Vol. 1. p. $77-87$. 